\title{
The Influence Effect of Entrepreneurial Orientation and Funding Decision Toward the Business Performance (A Study on of SMEs on Bali)
}

\author{
Imam Kreswanto, Agus Putra Mardika, Anik Puspa Ningsih \\ Universitas Warmadewa, Denpasar, Bali - Indonesia \\ imamkreswanto91@gmail.com
}

\begin{abstract}
SMEs spa products are currently being sought by local and foreign tourists. SMEs spa product in Bali has been able to penetrate the international market. Various problems faced by SMEs cause interference to increase business performance. Business performance is measured by financial performance of SMEs. The present study determines the financial performance of SMEs spa, viewed of the funding decisions and entrepreneurial orientation. The subjects are 8 spa products existing in SMEs Bali registered in the Department of Cooperative and SMEs Bali Province. Data analysis was carried out using partial least squares (PLS). It was found that the entrepreneurial orientation has a positive and significant impact on the sustainability of the business. Funding decision significantly has positive effect on business continuity and entrepreneurial orientation.
\end{abstract}

Keywords: funding decisions, entrepreneurial orientation, financial performance and SMEs

\section{Introduction}

SMEs contributed to Gross Domestic Product (GDP) reaching 57.84\% in 2010 and increased to $60.34 \%$ in 2015 (Business Profile of UMKM by LPPI and BI, 2016). SMEs also contribute to the Gross Regional Domestic Product of Bali, which reaches 22.75 percent (BPS, 2018). The growth of SMEs in Bali reached 313,822 in 2017, an increase of $9.63 \%$ from the previous year (Dinas Koperasi UKM Provinsi Bali, 2018).

The Ministry of Industry (2014) states the national cosmetics industry contributed a significant portion of value to the export, turnover, and labor. Data from the Ministry of Industry in 2017 the cosmetics industry was able to help the national economy with a significant contribution. Therefore, breakthrough for the development of production and improving the competitiveness of the cosmetic industry should be improved. Based on data of 2017, cosmetics industry sales value reached 19 Trillion rupiah. The figure rose 11.99 percent compared to that of 2016. The average growth rate of cosmetics exports within the last five years reached 3.56 percent. In 2018, the cosmetics industry export target of 1.67 billion US dollars.

Dewi (2012) stated that Bali as a main tourist destination is famous domestic and foreign tourists has advantages in the field of body care business. Spa Products Manufacturer Association (2015) states that Bali has evolved into a destination spa so many businesses in the field of spa products in Bali. SMEs that focus on spa products in the form of Balinese 
scrubs, massage oils, natural soaps, and aromatherapy essential oil capabilities are already far better. Increased production capacity of SMEs spa products becomes working capital to face increasingly sharp competition between local Balinese competitors, domestic competitors, and foreign competitors. In the case of the production of herbal soaps and scrubs for example, most entrepreneurs generally use local raw materials in the form of spices that are widely grown by farmers. On the other hand, he also did not dismiss the fact that the majority of cosmetic raw materials still have to be imported from abroad. Similarly, some machines and equipment whose technology is quite high still have to be imported. The packaging problem that is not only required to be hygienic, but also capable of encouraging the purchasing power of the people, becomes a separate issue that needs to be addressed together. In addition, another important, which until now has been the concern of the spa product manufacturers association in Bali is the plan to implement ISO 90012008, the application of good manufacturing processes and the implementation of quality control groups.

SMEs in Bali spa products are growing due to demand and the needs of local travelers and foreign tourists are so very high. SMEs Spa has been able to penetrate the international market. Based on the results of direct interviews with owner of UD Bungan Jepun on September 6, 2018, the spa product business turnover in 2017 amounted to \$230,000 and 20 percent came from export markets.

However, there are still many obstacles faced by SMEs spa products, among others, financing, competition, networking, human resources and competencies, technology, marketing, and sourcing of raw materials. Various problems faced by SMEs cause interference to increase business performance. Business performance is measured by financial performance of SMEs. SME financial performance is influenced by many variables such as funding decisions, in this case is the decision of the use of capital, should be managed optimally for causing a permanent burden for the company. In addition, Funding Decision, entrepreneurial orientation is required to carry out operational activities better to keep the financial performance of a business. Orientation entrepreneurial (nature innovative, proactive and ability to manage risk) owned by management or owners of the company will be able to determine the development of a business. Growing businesses will require a relatively large funding. If the funding source is not sufficient internal funding needs, the company will seek sources of funding from outside the company that is debt.

The object of this study is 8 spa products existing SMEs Bali Province registered in the Department of Cooperatives and SMEs Bali Province. Data analysis was performed using partial least squares (PLS).

This study aims to determine the financial performance of SMEs spa products in Bali, judging by the decisions of funding and entrepreneurial orientation.

\subsection{Performance}

Sefiani \& Bown (2013) suggests that performance is an indicator used to measure the goals and objectives set. Business actors make performance a top priority [1]. Gibcus \& Kemp suggests that business performance relies heavily on the right management approach that involves three levels of management. The authors further mention that business performance measures market-related items such as sales growth and market share and the company's future position. One indicator of corporate performance is financial performance.

Financial performance is the main outcome organizational effectiveness. Though the performance standards considered vital, it is sufficient to determine the overall effectiveness. Accounting-based organizational effectiveness considers the profitability in terms of Return on Sales (ROS), Return on Assets (ROA) and Return on Equity (ROE) to measure financial 
performance. The steps of organizational effectiveness tend to be more complex towards stakeholders than to shareholders. There are indicators in terms of quality, such as product quality, employee satisfaction, and overall quality indicators related to social responsibility such as environmental and community responsibility.

\subsection{Funding Decision}

A company in running its business in line with the development experienced, always in need of additional capital. At the time the company is founded, the owner can determine the source of capital for what to wear, whether all sourced from the ordinary share capital or need no long-term debt. Every decision made about the source of capital is always an impact.

Basically there are two theories behind the selection of the most important thing in the capital structure of SMEs [2]. First, the trade-off theory: the theory shows that every company has an optimal capital structure. When a balance between income and additional debt is formed, optimal minimization of debt can be achieved. Of the many benefits associated with debt, the benefits of taxes are the benefits of interest payments that are supportive for debt reduction (Modigliani and Miller, 1963; DeAngelo and Masulis, 1980). Another benefit is the reduction in agency problems that arise between shareholders and managers related to free cash flow (Jensen 1986). Among the losses associated with debt, the cost of financial pressure (Myers 1977) and agency costs that arise between owners and financial creditors (Jensen and Meckling 1976; Myers 1977) stand out when the level of debt increases.

Secondly, the pecking-order theory proposed by Myers (1984) and Myers and Majluf (1984) claim that there is no optimal debt ratio. Instead, companies adjust the company's financial decisions with hierarchies because of the problem of asymmetric information between managers and investors in relation to external funding. First, companies prefer internal funding rather than external funding. Second, only if internal funds are insufficient, they use external funds. Among external resources, they prefer debt and leave new equity as the last alternative for resources. Asymmetric information problems are very relevant for SMEs, because they are more opaque than large companies are.

\subsection{Entrepreneurial Orientation}

Entrepreneurial orientation is the tendency to act autonomously, to innovate, to take risks and, to be proactive when being faced with a business opportunity [3]. Entrepreneurial orientation in several studies measured the dimensions of innovation, proactive and courage to manage risk [4]. Lumpkin and Dess (1996) defines innovation as "the tendency of companies to engage in and support new ideas, novelty, experimentation, and creative process that can produce a new product, service, or process" [3]. Rauch et al. (2009) describes it as a desire of employers to encourage and support creativity experimentation in the form of the launch of new products or services or better or in terms of technological supremacy by research and development in organizational procedures.

Vora et al (2012) explains that the company attributes proactively trying to look for opportunities in the future in spite of the fact that this opportunity may not even be related to the company's current operations. They further describe that these companies identify and take advantage of opportunities to meet the demand, perhaps through their own innovation.

Rauch et al. (2009) explains that taking risks is the tendency of companies to take bold steps, perform calculated risks, employ a lot and most of the resources invested fir and into an uncertain market and are not known to take business opportunities. Lumpkin and Dess (1996) considers risk-taking as a quality company that is crucial for the survival, growth and superior performance of the company [3]. These three dimensions: risk taking, innovation and 
proactive is very important for the company because they affect the company's performance in the current business environment (Brettel and Rottenberger, 2013).

\subsection{Relationship between Entrepreneurial Orientation and Funding Decision}

Entrepreneurial orientation formed by three dimensions: the ability to innovative, proactive, and a tendency to take risks (propensity for risk taking) [5]. The ability to innovate reflects the tendency of employers to find and engage with new ideas [3]. The second dimension is proactive reflect employers' ability to find and exploit new product opportunities and market opportunities to compete [6]. The tendency to take risks is a dimension of the most important entrepreneurial orientations and is defined as the tendency of companies to be involved in projects that have a specific goal [6].

The results of research by Wiagustini, et al showed that the entrepreneurial orientation positive and significant impact on the funding decision [7]. The higher the orientation owned a company determines the amount of funding, internal or external companies. Nofsinger and Wang (2011) argue that when the company's internal funds are insufficient to cover business development occurs then the required additional funding from financial institutions.

\subsection{Funding Decision and Financial Performance}

Sudarmakiyanto et al (2013) research on the property sector companies, real estate and building construction listed in Indonesia stock exchange period 2008-2012 found that the financing decision significantly positive impact on financial performance [8]. Ahmad et al (2012) found that the use of long-term debt and short-term has a significant positive correlation with profitability [9]. Skopljak and Luo (2012) conducted a study in Australia related to the financing decision relationship with company performance, the findings indicate a significant positive relationship between capital structure which is a funding decision by the company's performance [10]. Davydov (2016) who conducted research in BRIC countries found that the decision of funding proxied by the debt structure had a positive and significant effect on financial performance, companies that used bank debt had better performance [11].

However, different research Warmana Oka (2017) found that the maturity structure of the debt is a significant negative effect on financing decisions on financial performance, the use of long-term debt have a negative impact on financial performance [12]. While the research of David et al. (2016) found no effect of capital structure significantly on financial performance [13].

\subsection{Entrepreneurial Orientation and Financial Performance}

There are many studies on the relationship between entrepreneurial orientation and financial performance. Some research shows significant results and positive relationships including Magaji et al (2017) stated that the entrepreneurial orientation of the positive and significant impact on performance, proactive firm characteristics such as responsive to market signals, have access to scarce resources, and is committed to improve the products and services will increase returns on high performance of a company [14]. Mukhtar Shehu Aliyu and Rosli (2014) found a significant positive relationship between entrepreneurial orientation and financial performance [15].

Entrepreneurial orientation that is proxied by the dimensions of risk taking is positively significant related to company performance [3]. Hakala's research (2013) found that Entrepreneurial Orientation has a significant positive influence on company performance as 
measured by the company's profitability [16]. Entrepreneurial orientation has a significant positive effect on the performance of SMEs in the Netherlands [17].

\subsection{SMEs}

Small businesses and macro businesses, as determined by the State Ministry for Cooperatives, Small and Medium Enterprises, include business entities with maximum net worth are IDR. 200,000,000, - excluding land and buildings for businesses, and has annual sales of at most IDR. 1,000,000,000. Medium Business is a business entity owned by Indonesian citizens with net worth greater than IDR. 200,000,000 up to Rp. 10,000,000,000, outside land and buildings.

\subsection{Spa Product}

SPA comes from the Latin language and is taken from the term sante par aqua or solus per aqua, which means healthy through water therapy. Along with its development, SPA developed into a place of beauty, body care, health, fitness, and comfort. Body care is in great demand and is important for both women and men. Activities to carry out body care become a necessity that must be met. A great opportunity in the body care industry is an advantage that is used by various parties to build a business producing various body care products. Bali has added value to this because in addition to being a tourist destination Bali is also rich in spices and natural resources that are safe to be used as skin care products or SPA products.

SMEs spa products in Bali produce various types of body care products with natural ingredients, the types of products produced are body care products ranging from toe to hair tip. The products presented by SMEs product spa consist of 5 categories, namely aromatherapy, foot care, hair care, body care, and facial care. This spa product is produced using natural traditional ingredients, manufactured products include message oil, skin nutrition face and body mask, body mist, body butter, body lotion, shower gel, scrub cream, and other products. Various products presented by UKM spa have different functions according to needs.

\section{Results and Discussion}

\subsection{Entrepreneurial Orientation and Funding Decision}

The results of data analysis showed that the proportion of debt to SMEs measures the effect of entrepreneurial orientation towards the funding decision spa products are have a significant and negative effect on funding decisions. The magnitude of the effect is -0.824 with a significance of $\mathrm{p}<0.01$. The findings of this study inform that, the higher the level of entrepreneurial orientation owned by business owners of spa products that are available, resulting in low funding decisions, this is seen from the use of debt.

Table 1. Path Coefficients and P-Values Analysis

\begin{tabular}{ccccccc}
\hline \multicolumn{7}{c}{ Path Coefficient } \\
\hline & Inn & Pro & Risk & FD & FP & FD*FP \\
\hline EO & 0.891 & -0.967 & 0.974 & -0.824 & 0.096 & 0.891 \\
\hline & \multicolumn{7}{c}{ P-Values } \\
\hline EO & $<0.001$ & $<0.001$ & $<0.001$ & $<0.001$ & 0.387 & $<0.001$ \\
\hline
\end{tabular}


Spa product entrepreneurs prefer to use their own capital rather than using capital from banks or financial institutions in the form of debt. Because every capital that comes from bank debt will generate interest and installments every month. Although there is a huge turnover in the business of spa products, business owners do not dare to use bank loans, business owners are worried that they cannot meet liquidity. This is because sales of spa products are still unstable; on the one hand, Bali is only dependent on the tourism sector that is vulnerable economy plus many customers who make orders with credit with terms of payment up to 90 days. The results of this study are findings, and rejecting the theory of increasing entrepreneurial orientation will increase funding decisions proxied by the use of debt. The results of this study, in contrast to the findings of Wiagustini, et al (2017) show that entrepreneurial orientation has a significantly positive effect on funding decisions [7].

\subsection{Entrepreneurial Orientation and Financial Performance}

Based on the results of data analysis, the entrepreneurial orientation has insignificantly positive impact on financial performance. The magnitude of the effect is 0.390 and the significance is $\mathrm{p}=0.39>0.01$. This shows that, the higher the level of entrepreneurial orientation of spa business, the less the financial performance increases.

The finding of the study enforces the theory claiming that the higher the level of entrepreneurial orientation of a business, the better its financial performance will be. In contrast, this finding is contrary with different notion stating that entrepreneurial orientation has a positive and significant impact on financial performance (Aliyu and Rosli, 2014; Rauch et al., 2004; Hakala 2013; Kraus et al., 2012). Moreover, it contradicts the concept that the characteristics of the company have always been to innovate, to take risks, and to be proactive and they will improve the company's financial performance (Magaji et al., 2017).

\subsection{Funding Decision and Financial Performance}

In terms of relation between funding decision and financial performance, the finding of the present study indicates that the funding decision has a significantly positive on financial performance. The magnitude of the effect is 0.89 with a significance of $p<0.01$. Thus, an increase in the use of bank debt or a certain proportion of financing institutions will improve the financial performance. The more the capital owned by businesses, the great the possibility for business enterprises to innovate, expand, improve technology, increase production, and to increase exports; therefore there a number of coming opportunities that increase profits, the company's financial performance - which in this study is measured with sales volume, improved earnings, and increased company's assets.

These results are consistent with the results of previous studies conducted among Davydov (2016), Sudarmakiyanto et al. (2013), Ahmad et al. (2012), and Skopljak and Luo (2012) which found that the funding decision shares significantly positive impact on financial performance. In addition, the results do not correspond with the results of the research of Oka (2017), which found that funding decisions significantly has negative effects on financial performance and the use of long-term debt has a negative impact on financial performance. 


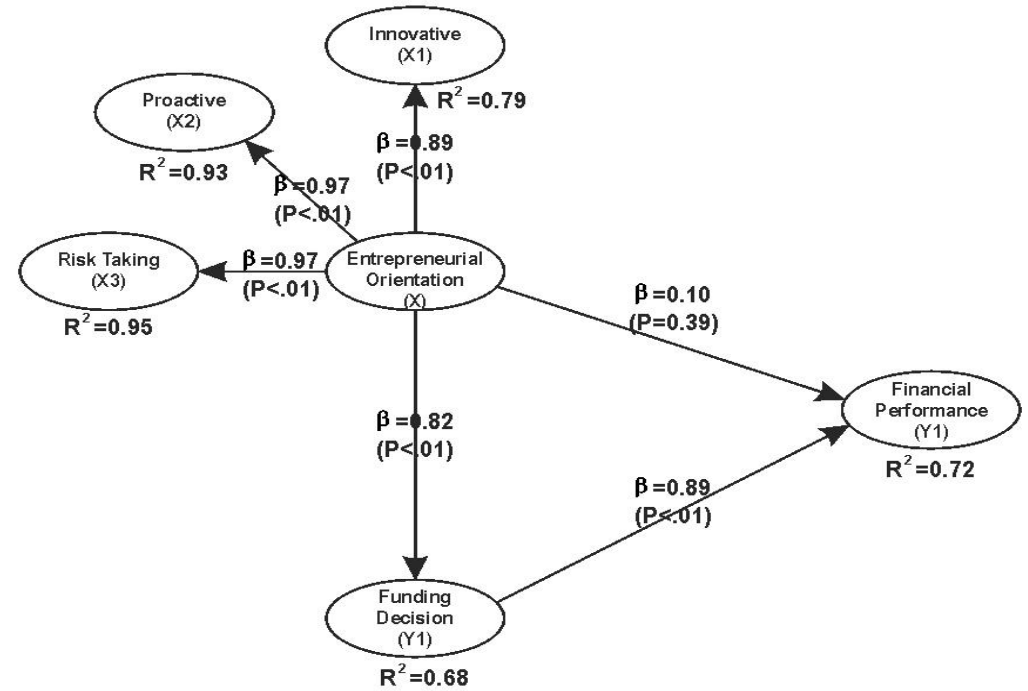

Figure 1. Funding and Financial Performance

\section{Conclusion}

Entrepreneurial orientation has a significant negative effect on financing decision. The higher entrepreneurial orientation would not make SMEs manager using a large amount of capital. Entrepreneurial orientation has a significantly negative effect on financing performance. The higher entrepreneurial orientation would not increasing financial performance of SMEs of SPA product directly. This study only tested the financial performance of SMEs spa product in Bali, judging by the decisions of funding and entrepreneurial orientation. Future studies could examine other factors on which the sustainability of the business, including marketing aspects that exist in SMEs spa products, in order to obtain more comprehensive results.

\section{Acknowledgment}

I am very grateful to God, my parents, friends and family who have helped in this study and for the editorial boards and publishing team of EAI Publisher for the contribution to the process of publishing this paper.

\section{References}

[1] R. Sefiani, Y., \& Bown, "What influences the success of manufacturing SMEs? A perspective from tangier," Int. J. Bus. Soc. Sci., vol. 7, no. 4, pp. 15-29, 2013.

[2] M. H. Asad, Muzaffar., Shariff, Mohd Noor Mohd., \& Hafeez, "Moderating Effect of Network Ties on the Relationship Between Entrepreneurial Orientation, Market Orientation, and Performance of MSES," A Res. J. Commer. Econ. Soc. Sci., vol. 10, no. 2, pp. 74-81, 2016.

[3] G. G. Lumpkin, G T., \& Dess, "Linking two dimensions of entrepreneurial orientation to firm performance: The moderating role of environment and industry life cycle," $J$. 
Bus. Ventur., vol. 16, no. 5, pp. 429-651, 2001.

[4] S. Miller, W. R., \& Rollnick, Motivational interviewing: Preparing people to change addictive behavior. New York: Guilford Press, 1991.

[5] L. Fitri, "Pengaruh Orientasi Wirausaha dan Kapabilitas Jejaring usaha Terhadap Peningkatan Kinerja UKM dengan Komitmen Perilaku sebagai variabel intervening," J. Organ. dan Manaj. STIE BPD Jateng, 2012.

[6] P. Miller, Danny., \& Friesen, "The Longitudinal Analysis of Organizations: A Methodological Perspective," Manage. Sci., vol. 28, no. 9, pp. 1013-1034, 1982.

[7] L. G. S. Wiagustini, Ni Luh Putu., Ningsih, Ni Luh Anik Puspa., \& Artini, "Budaya 'Catur Purusa Artha' dan Orientasi Kewirausahaan sebagai Basis Keputusan Pendanaan dan Kinerja Keuangan,” Proceeding Semin. Nas. AIMI Jambi, 2017.

[8] P. Sudarmakiyanto, Eko., Prasetya, Hery., \& Anoraga, Pengaruh Keputusan Keuangan Terhadap Kinerja Keuangan (Studi Empiris pada Perusahaan Sektor Property, Real Estate, dan Building Construction yang Terdaftar di Bursa Efek Indonesia Periode 2008-2012) Indonesia. 2013.

[9] N. M. Zuraidah, Ahmad., Abdullah., \& Hasan, "Capital Structure on Firma Performance: Focusing on Consumers and Industrial Sectors on Malaysia Firma," Int. Rev. Bus. Reasearch Pap., vol. 8, no. 5, pp. 137-155, 2012.

[10] R. Skopljak, Vedran., \& Luo, "Capital Structure and Firm Performance in the Financial Sector :Evidence form Australia," Asian J. Financ. Account., vol. 4, no. 1, 2012.

[11] D. D, "Debt structure and corporate performance in emerging markets," Res. Int. Bus. Financ., vol. 38, pp. 299-311, 2016.

[12] I. W. Warmana, G Oka., \& Widnyana, "Pengaruh keputusan pendanaan terhadap kinerja keuangan perusahaan pada sektor pariwisata, restoran dan hotel yang ada di Bali," vol. 12, no. 2, 2017.

[13] E. WMNW, Daud., NM, Norwani., AA, Mansor., \& WA, "Does Financing Decision Influence Corporate Performance in Malaysia?," Int. J. Econ. Financ., vol. 6, no. 3, pp. 1165-1171, 2016

[14] A. Magaji, Mohammed Sanusi., Baba, Ricardo., \& Entebang, "Entrepreneurial orientation and financial performance of nigerian smes: the moderating role of environment a review of literature," J. Manag. Train. Ind., vol. 4, no. 1, 2017.

[15] R. Aliyu Mukhtar, Shehu., \& Mahmood, "Influence of Entrepreneurial Orientation and Business Environment on Small and Medium Firm Performance," Adv. Manag. Appl. Econ., vol. 4, no. 4, pp. 101-111, 2014.

[16] H. H, "Entrepreneurial and Learning Orientation : Effect on Growth and Profitability in the Software Sector," Balt. J. Manag., 2013.

[17] M. A. Hussain, Jawad., Abbas, Qamar., \& Khan, "Entrepreneurial Orientation and Performance: The Moderating Effect of Market Orientation," GMJACS, vol. 7, no. 1, 2017. 